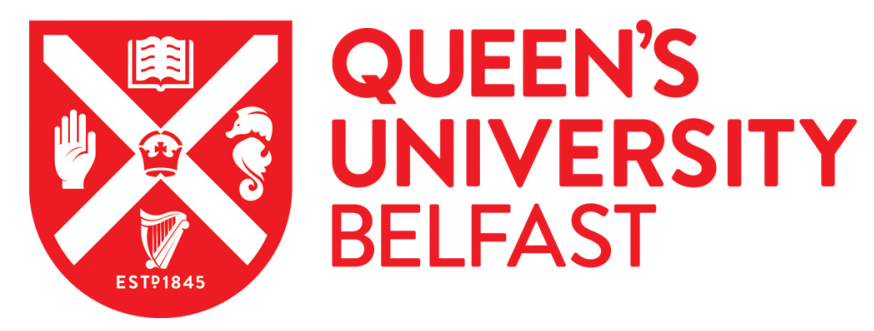

\title{
Absence of CALR Mutations in Idiopathic Erythrocytosis Patients with Low Serum Erythropoietin Levels
}

Catherwood, M. A., Graham, A., Cuthbert, R. J. G., Garrec, C., Gardie, B., Girodon, F., Laird, S., Cross, N. C. P., \& McMullin, M. F. (2018). Absence of CALR Mutations in Idiopathic Erythrocytosis Patients with Low Serum Erythropoietin Levels. Acta haematologica, 139(4), 217-219. https://doi.org/10.1159/000489006

Published in:

Acta haematologica

Document Version:

Peer reviewed version

Queen's University Belfast - Research Portal:

Link to publication record in Queen's University Belfast Research Portal

\section{General rights}

Copyright for the publications made accessible via the Queen's University Belfast Research Portal is retained by the author(s) and / or other copyright owners and it is a condition of accessing these publications that users recognise and abide by the legal requirements associated with these rights.

Take down policy

The Research Portal is Queen's institutional repository that provides access to Queen's research output. Every effort has been made to ensure that content in the Research Portal does not infringe any person's rights, or applicable UK laws. If you discover content in the Research Portal that you believe breaches copyright or violates any law, please contact openaccess@qub.ac.uk. 
Absence of CALR mutations in idiopathic erythrocytosis patients with low serum erythropoietin levels

MA Catherwood ${ }^{1}$,A Graham ${ }^{1}$, RJG Cuthbert ${ }^{1}$, C Garrec $^{2,3}$, B Gardie ${ }^{2,3}$, F Girodon ${ }^{4,5}$, S Laird ${ }^{6}$, NCP Cross $^{6}$, MF McMullin ${ }^{1,7}$

${ }^{1}$ Clinical Haematology, Belfast City Hospital, BHSCT Belfast, Northern Ireland.

${ }^{2}$ Ecole Pratique des Hautes Etudes (EPHE), PSL Research University, France.

IINSERM U892, CNRS 6299, Université de Nantes, France.

${ }^{4}$ Service d'Hématologie Biologique CHU Dijon, France.

5INSERM, UMR866, University of Burgundy Franche-Comté, Dijon, France.

${ }^{6}$ Wessex Regional Genetics Laboratory, Salisbury, UK

${ }^{7}$ Centre for Medical Education (CME), Queen's University Belfast, Northern Ireland.

Correspondence to:

Prof. Mary Frances McMullin, Clinical Haematology, Belfast City Hospital, BHSCT Belfast, BT9 7AB. Northern Ireland.

Tel 02895048008: FAX: 02895048007: e-mail:m.mcmullin@qub.ac.uk

Key words: Idiopathic erythrocytosis, JAK2, calreticulin, erythropoietin

Short Title: CALR mutations in idiopathic erythrocytosis 
Idiopathic erythrocytosis (IE) is a heterogeneous collection of rare haematologic disorders which can be either sporadic or familial in origin (McMullin et al, 2005). An erythrocytosis occurs when there is an increased red cell mass and an elevated haematocrit. IE is distinct from polycythaemia vera (PV) as the red cell hyperplasia present in IE is not accompanied by elevations in the megakaryocytic or granulocytic lineages and PV is characterized by low serum erythropoietin (Epo) levels, whereas IE is associated with a wide range of Epo levels. IE can be divided into two main groups. The first group consists of those with a low EPO level suggesting an unidentified molecular defect possibly involving components of the Epo signal transduction pathway (de la Chapelle et al, 1993). The second group are those with inappropriately normal or raised EPO level which suggests a secondary unidentified cause possibly affecting the oxygen sensing pathway. These patients are rarely observed in clinical practice, and little is known regarding their clinical characteristics, natural history and best management.

Recently, novel frameshift mutations in exon 9 of the calreticulin (CALR) gene were found in patients with JAK2 or MPL unmutated primary myelofibrosis and essential thrombocythemia (ET) (Klampfl et al, 2013; Nangalia et al, 2013). Even though mutations of CALR have been reported in significant numbers in MPN it was initially thought that CALR mutations did not occur in PV. However in 2014 two JAK2 negative PV patients were described that harboured CALR mutations (52 bp deletion) (Broseus et al, 2014) with further cases described in other studies (Chauveau et al, 2017).

The aims of this study were to assess the prevalence of CALR mutations in (i) a well characterized cohort of IE patients with low serum erythropoietin levels and (ii) a broad cohort of query myeloproliferative neoplasm (MPN) cases referred for molecular genetic investigation.

Initially we studied 79 patients with IE. Thirty eight were enrolled from a UK cohort and 41 from a French cohort.

Ethical approval was granted by the local review committees and informed consent was collected according to the Helsinki Declaration.

All the patients had low to normal serum EPO level (Table 1) and none of them carried JAK2V617F or JAK2 exon 12 mutations as determined by allele specific PCR. Clinical and laboratory details of the patients are shown in Table 1. The procedures followed were in accordance with the Declaration of Helsinki and all patients gave informed written consent. CALR exon 9 mutations were screened by fragment length analysis according to Klampfl et al, 2013.

The patients were mostly males in both the groups with a higher frequency in the French cohort. Patients in both cohorts had similar characteristics (Table 1). No CALR mutations were detected in any of the 79 IE patients included in this study with low to normal EPO levels.

To further explore the possibility of CALR mutations in PV we audited samples referred for MPN panel analysis at the Wessex Regional Genetics Laboratory (WRGL) in Salisbury (Jones et al, 2015). Since October 2016 all query MPN referrals to the WRGL have been tested using an ampliconbased next generation sequencing approach for JAK2 V617F, JAK2 exon 12, MPL exon 10 and CALR exon 9 mutations irrespective of their phenotype. Of 2306 referrals, 137 (5.9\%) tested positive for $C A L R+1$ frameshift mutations. None of the 659 referrals that specified an erythroid phenotype PV, ?PV, high haematocrit or high haemoglobin) tested positive for CALR mutations. 
In previous studies 4 CALR mutations have been identified in so called JAK2 negative PV in patients more accurately described as JAK2 negative unexplained erythrocytosis. In the first study only 2 patients were studied (Broseus et al, 2014). Both cases were JAK2 negative PV and the CALR mutation was a $52 \mathrm{bp}$ deletion, commonly termed type 1 mutation. Of note, both patients had thrombocytosis in addition to erythrocytosis. In the second study a large cohort of 578 patients were examined (Chauveau et al, 2017). Of the two patients with CALR mutations one was subsequently considered to have ET with slightly increased red cell mass and the other considered to have idiopathic erythrocytosis. Both cases harboured the $52 \mathrm{bp}$ deletion. Of interest, in the patient with idiopathic erythrocytosis the CALR mutation was detected with a low allele burden of approximately $5 \%$.

The underlying defect in cases with unexplained erythrocytosis provides a clinical conundrum. Our findings indicate that CALR mutations are absent in a cohort of 79 patients with IE and also in a large, broad real-life cohort of patients with an erythroid phenotype referred for MPN panel testing. We therefore consider that the screening of CALR mutations in this situation is not warranted as a standalone investigation.

\section{"Disclosure Statement"}

The authors declare no conflicts of interest. 


\section{References}

1. McMullin MF, Bareford D, Campbell P, Green AR, Harrison C, Hunt B, Oscier D, Polkey MI, Reilly JT, Rosenthal E, Ryan K, Pearson TC, Wilkins B; General Haematology Task Force of the British Committee for Standards in Haematology. Guidelines for the diagnosis, investigation and management of polycythaemia/erythrocytosis. Br J Haematol, 2005;130:174-195

2. de la Chapelle A, Träskelin A-L, Juvonen E (1993). Truncated erythropoietin receptor causes dominantly inherited human erythrocytosis. Proc Natl Acad Sci; 1993;90:4495-4499.

3. Klampfl T, Gisslinger $H$, Harutyunyan AS, Nivarthi $H$, Rumi E, Milosevic JD, Them NC, Berg T, Gisslinger B, Pietra D, Chen D, Vladimer GI, Bagienski K, Milanesi C, Casetti IC, Sant'Antonio E, Ferretti V, Elena C, Schischlik F, Cleary C, Six M, Schalling M, Schönegger A, Bock C, Malcovati L, Pascutto C, Superti-Furga G, Cazzola M, Kralovics R. Somatic mutations of calreticulin in myeloproliferative neoplasms. N Engl J Med 2013;369:2379-2390.

4. Nangalia J, Massie CE, Baxter EJ, Nice FL, Gundem G, Wedge DC, Avezov E, Li J, Kollmann K, Kent DG, Aziz A, Godfrey AL, Hinton J, Martincorena I, Van Loo P, Jones AV, Guglielmelli P, Tarpey P, Harding HP, Fitzpatrick JD, Goudie CT, Ortmann CA, Loughran SJ, Raine K, Jones DR, Butler AP, Teague JW, O'Meara S, McLaren S, Bianchi M, Silber Y, Dimitropoulou D, Bloxham D, Mudie L, Maddison M, Robinson B, Keohane C, Maclean C, Hill K, Orchard K, Tauro S, Du MQ, Greaves M, Bowen D, Huntly BJ, Harrison CN, Cross NC, Ron D, Vannucchi AM, Papaemmanuil E, Campbell PJ, Green AR. Somatic CALR mutations in myeloproliferative neoplasms with nonmutated JAK2. N Engl J Med 2013;369:2391-2405.

5. Jones AV, Ward D, Lyon M, Leung W, Callaway A, Chase A, Dent CL, White HE, Drexler HG, Nangalia J, Mattocks C, Cross NC. Evaluation of methods to detect CALR mutations in myeloproliferative neoplasms. Leuk Res. 2015;39:82-87.

6. Broséus J, Park JH, Carillo S, Hermouet S, Girodon F. Presence of calreticulin mutations in JAK2 negative polycythemia vera. Blood 2014;124:3964-3966.

7. Chauveau A, Nibourel O, Tondeur S, Paz DL, Mansier O, Paul F, Wemeau M, Preudhomme C, Lippert E, Ugo V; French Intergroup of Myeloproliferative Neoplasms (2017). Absence of CALR mutations in JAK2-negative polycythemia. Haematologica 2017;102:e15-e16.

8. Percy MJ, Scott LM, Erber WN, Harrison CN, Reilly JT, Jones FG, Green AR, McMullin MF. Haematologica 2007;92:1607-1614. 


\section{Authorship}

AG analysed the data, wrote the paper and performed the molecular analysis. MC, AG, SL and BG performed the molecular analysis. RJGC contributed clinical data and followed the patients. MFM, NCPC and FG designed the study, recruited patients and critically reviewed the manuscript. All authors have read and approved the final version.

Table 1. Patients characteristics.

UK 


\begin{tabular}{|c|c|c|}
\hline & Mean & Range/percentage \\
\hline Sex, female:male & $11: 27$ & $29 \%$ female \\
\hline Age & 54 & $27-75$ \\
\hline Haemoglobin level, g/L & 198 & $169-249$ \\
\hline Hematocrit, \% & 57 & $49-79$ \\
\hline Platelet count, $10^{9} / \mathrm{L}$ & 220 & $119-467$ \\
\hline White blood cells, $10^{9} / \mathrm{L}$ & 8.3 & $4.2-15.6$ \\
\hline Erythropoietin level, $\mathrm{mIU} / \mathrm{mL}$ & 5.8 & $1-9.9$ \\
\hline
\end{tabular}

FRENCH

\begin{tabular}{|c|c|c|}
\hline & Mean/ratio & Range/percentage \\
\hline Sex, female:male & $3: 38$ & $5 \%$ female \\
\hline Age & 48 & $13-79$ \\
\hline Haemoglobin level, g/L & 186 & $161-230$ \\
\hline Hematocrit, \% & 52.7 & $46-66$ \\
\hline Platelet count, $10^{9} / \mathrm{L}$ & 215 & $139-350$ \\
\hline White blood cells, $10^{9} / \mathrm{L}$ & 7.7 & $5.34-9.14$ \\
\hline Erythropoietin level, $\mathrm{mIU} / \mathrm{mL}$ & 11.35 & $1.7-30$ \\
\hline
\end{tabular}

BOTH

\begin{tabular}{|c|c|c|}
\hline & Mean/ratio & Range/percentage \\
\hline Sex, female:male & $14: 65$ & $18 \%$ female \\
\hline Age & 51 & $13-79$ \\
\hline Haemoglobin level, g/L & 192 & $161-249$ \\
\hline Hematocrit, \% & 54 & $46-79$ \\
\hline Platelet count, $10^{9} / \mathrm{L}$ & 218.5 & $119-467$ \\
\hline White blood cells, $10^{9} / \mathrm{L}$ & 8 & $4.2-15.6$ \\
\hline Erythropoietin level, $\mathrm{mIU} / \mathrm{mL}$ & 8.6 & $1.7-30$ \\
\hline
\end{tabular}

